\title{
Flatfish (Pleuronectiformes) species richness and depth distribution in the Gulf of Nicoya, Golfo Dulce, and two adjacent areas on the Pacific coast of Costa Rica
}

\author{
José A. Vargas 1,4*, Ana R. Ramírez ${ }^{2}$, Berny Marín ${ }^{3}$, Myrna I. López ${ }^{2} \&$ Matthias Wolff ${ }^{5}$ \\ 1. Escuela de Biología, Universidad de Costa Rica, 11501-2060, San José, Costa Rica; jose.vargas@ucr.ac.cr \\ 2. Museo de Zoología, Escuela de Biología, Universidad de Costa Rica, 11501-2060, San José, Costa Rica; \\ ana.ramirezcoghi@ucr.ac.cr, myrna.lopez@ucr.ac.cr \\ 3. Instituto Nacional de Pesca y Acuicultura (INCOPESCA), San José, Costa Rica; bmarin@incopesca.go.cr \\ 4. Centro de Investigación en Ciencias del Mar y Limnología (CIMAR), Universidad de Costa Rica, 11501-2060, \\ San José, Costa Rica. \\ 5. Leibniz Centre for Tropical Marine Research (ZMT), Bremen, Germany; matthias.wolff@leibmiz-zmt.de \\ * Correspondance
}

Received 13-IV-2020. Corrected 15-VII-2020. Accepted 10-VIII-2020.

\begin{abstract}
Introduction: Information on the number of flatfish species and their depth distributions is scarce for the Eastern Tropical Pacific. Historical data is important to evaluate changes in ecosystems due to local, regional and global stressors. Objective: To provide information on the presence, depth distributions and lengths of flatfish species collected by trawl nets. Methods: Fish studies were conducted by trawling at four sites along the Pacific coast of Costa Rica by the survey vessels Skimmer (1979-1980), Nishin Maru (1987-1988) and Victor Hensen (1993-1994). The published lists of species were consulted, museum specimens were accessed, and an updated list of flatfish species assembled. Results: A total of 36 species were found over a depth range of 8-359 m. The family Paralichthyidae included 13 species followed by the Cynoglossidae with 12 species, Achiridae with six and Bothidae with five. Thirty-five species were collected at depths from 10-235 $\mathrm{m}$ in the Gulf of Nicoya and Golfo Dulce. Monolene asadeae was collected offshore at a depth range of 254-359 m. The Gulf of Nicoya estuary yielded 27 species during the Skimmer expedition over a depth range of 8-60 m, while 31 species were found during the V. Hensen survey at depths from 10-228 m. The V. Hensen survey in Golfo Dulce (20-235 m) collected 19 species, and 17 species in Coronado Bay (21-187 m). Off the Nicoya Peninsula (56-359 m) 13 species were collected by the Nishin Maru shrimp trawler. A total of 21 species (58 \%) were found at depths greater than $100 \mathrm{~m}$ which were probably exposed to low oxygen concentrations. During the V. Hensen survey Symphurus chabanaudi and S. elongatus were collected more frequently in the Gulf of Nicoya, while $S$. leei was collected more frequently in Golfo Dulce. Cluster analyses based on presence-absence data for the Gulf of Nicoya and Golfo Dulce revealed low station similarity indicating possible habitat partitioning among species. The size (Total length) of 33 species measured from both the Gulf of Nicoya and Golfo Dulce ranged from 8 $\mathrm{cm}$ (Syacium cf longidorsale, Trinectes xanthurus) to $50 \mathrm{~cm}$ (S. ovale). Only 12 species were found with lengths over $20 \mathrm{~cm}$. Data on flatfish landings by the semi-industrial fishing fleet for the period 2000-2016 indicates that this group represents less than $1 \%$ of the total landings (shrimp and bycatch), with a minimum of $365 \mathrm{~kg}$ in 2001 and a maximum of $13414 \mathrm{~kg}$ in 2013. Conclusions: The number of flatfish species of the Pacific coast of Costa Rica appears relatively high but comparable to the numbers found in other tropical regions. A reduced fishing
\end{abstract}

Vargas, J.A., Ramírez, A.R., Marín, B., López, M.I., \& Wolff, M. (2020). Flatfish (Pleuronectiformes) species richness and depth distribution in the Gulf of Nicoya, Golfo Dulce, and two adjacent areas on the Pacific coast of Costa Rica. Revista de Biología Tropical, 68(4), 1116-1130. 
impact on the populations together with this updated list of flatfish provide a good baseline for a new survey of fish populations. Both are important for a future updating of the trophic models available the Gulf of Nicoya and Golfo and their use as tools for better management of the ecosystems.

Key words: flounders; tonguefish; soles; estuary; benthos; trawling; Symphurus.

The fishes of the Order Pleuronectifornes, commonly known as flatfish, are characterized by a laterally compressed body and the adults have both eyes on one side of the head. They live on the bottom sediments lying on one side of the body. Flatfish (flounders, tonguefish, soles) are benthic predators and some species can bury themselves in the sediments to avoid predators and search for prey. Because of their benthic habitat they are frequently captured incidentally as by-catch by trawl nets used by shrimp fishing vessels. Most of the adult tropical flatfish captured are of small size, with total lengths of less than $40 \mathrm{~cm}$ and only larger specimens are usually saved for local comsuption or for sale at fish markets. The number of pleuronectiform species worldwide has been estimated to be 1042 (Nair \& Gopalakrishnan, 2014).

There appears to be more species of flatfish in the tropics than in temperate regions, being tropical species relatively smaller than temperate ones (Pauly, 1994). Local factors such as depth, sediment type and oxygen concentration may influence their local diversity and distribution (Gibson, 1994). Tropical flatfish studies usually provide scarce information on species identifications, depth and sediment types. For the Pacific coast of lower Central America, a total of 37 species of flatfish have been reported belonging to the families Achiridae, Bothidae, Cynoglossidae, and Paralichthyidae (Bussing \& López, 2015).

The Gulf of Nicoya estuary on the Pacific coast of Costa Rica has been its main fishing ground since the middle of the 20th century. Because of its commercial importance an ecological evaluation of its benthic fauna was conducted 40 years ago by the R.V. Skimmer using an otter trawl net at depths from 8 to $60 \mathrm{~m}$ and a list of species was published by Bartels, Price,
López \& Bussing (1983, 1984). More than a decade later during the R.V. Victor Hensen (hereinafter V. Hensen) expedition (1993-1994) the benthic fauna of the Gulf of Nicoya was sampled again with otter and beam trawl nets at depths from 10 to $228 \mathrm{~m}$. The resulting fish list was published by Bussing \& López (1996) and the ecological distributions were described by Wolff (1996). An updated list of the fish species collected in the Gulf of Nicoya by both vessels was published by, Vargas-Zamora, López-Sánchez and Ramírez-Coghi (2019) and yielded 32 species of flatfish (12\% of a total of 268 fish species) belonging to 13 genera (Achirus, Ancylopsetta, Cyclopsetta, Citharichthys, Engyophrys, Etropus, Hypoglossina, Monolene, Paralichthys, Perissias, Syacium, Symphurus and Trinectes). The richest genus was Symphurus, with 12 species.

The fish fauna of the deep Golfo Dulce embayment on the Southern Pacific coast of Costa Rica was also sampled as part of the V. Hensen expedition and included the nearby Coronado Bay. The list of fish species from both areas and their distributions were published by Bussing \& López (1996) and Wolff (1996), respectively. The fish fauna of the Northern waters of Costa Rica off the Nicoya Peninsula was sampled by the Nishin Maru shrimp trawler in 1987-1988 using an otter trawl and voucher specimens were deposited in the collection of the Museum of Zoology of the University of Costa Rica.

There are no reports focusing on the diversity and depth distribution of flatfish species along the Pacific coast of Central America. Updated information of the species diversity, depth distribution, and lengths of the species captured is important as a baseline for future studies aiming at the evaluation of the impact of local, regional and global stressors. Thus, 
the objective of this study is to provide complementary information on the presence, depth distribution and lengths of flatfish species collected by trawl nets in four coastal areas along the Pacific coast of Costa Rica.

\section{MATERIALS AND METHODS}

Most of the inner portion of the Gulf of Nicoya estuary is shallow (less than $50 \mathrm{~m}$ ) and
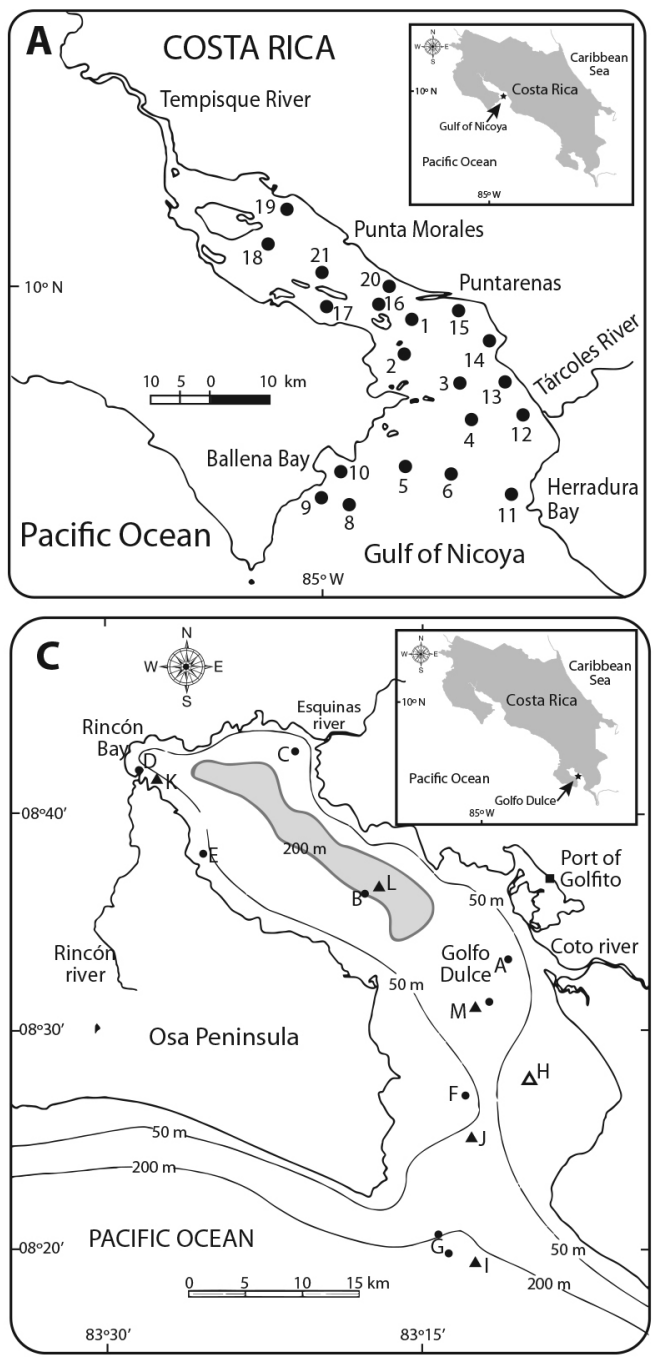

depth drops rapidly at the mouth. In contrast, the inner portion of the Golfo Dulce embayment is relatively deep $(200 \mathrm{~m})$ and has a sill $(60 \mathrm{~m})$ at the entrance. The Gulf of Nicoya is an estuary and its water dynamics have been described by Voorhis, Epifanio, Maurer, Dittel, and Vargas (1983). Golfo Dulce water circulation is more restricted, with hypoxic and anoxic waters below $100 \mathrm{~m}$ (Svendsen, Rosland, Myking, Vargas, Lizano, \& Alfaro,
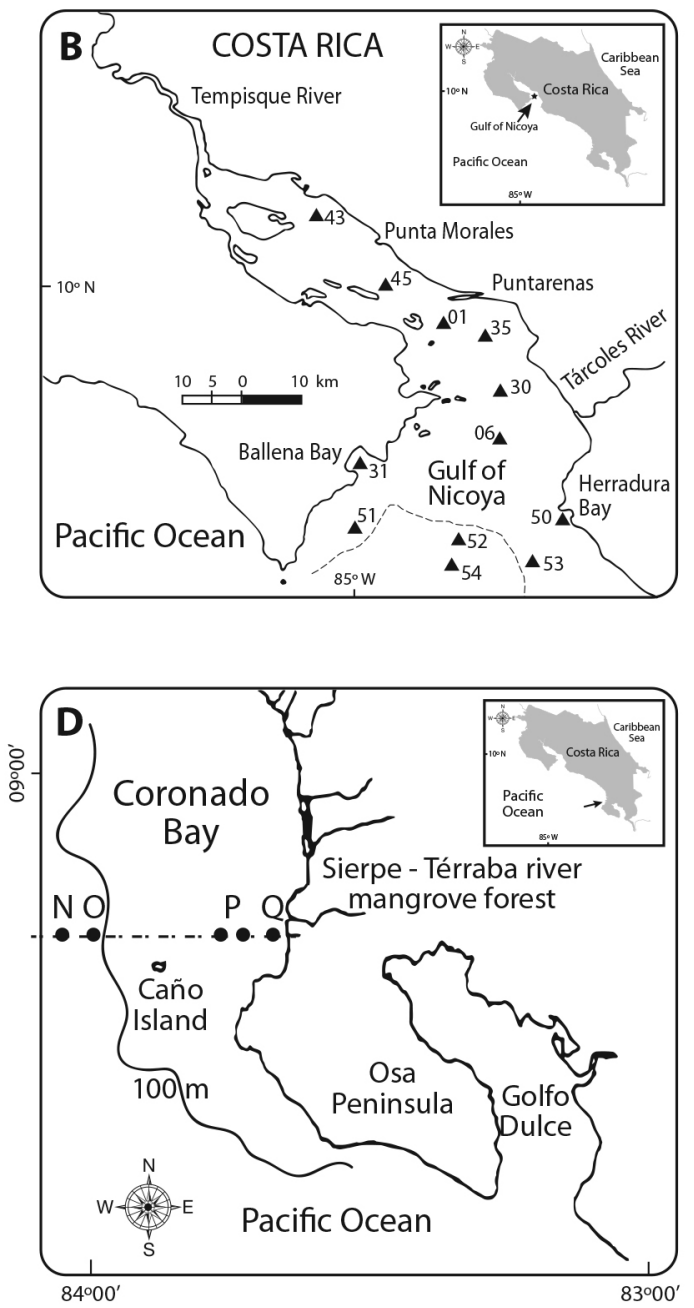

Fig. 1. Trawl sampling stations. Pacific coast of Costa Rica. A. Gulf of Nicoya, R.V. Skimmer (1979-1980, 20 stations, 8 to $60 \mathrm{~m}$ deep). B. Gulf of Nicoya, R.V. Victor Hensen (1993-1994, 12 stations, 10 to $228 \mathrm{~m}$ ), dashed line indicates the $100 \mathrm{~m}$ depth contour. C. Golfo Dulce, R. V. Victor Hensen (1993-1994, 13 stations, 20 to $235 \mathrm{~m}$ ) The shaded area includes depths over 200 m. D. Coronado Bay, R.V. Victor Hensen (1993-1994, 5 stations, 21 to $187 \mathrm{~m}$ ). 




Fig. 2. Shaded area: sampling zone $(56-359 \mathrm{~m})$ of the Nishin Maru shrimp trawler 1987-1988 For station positions see Table 4, Pacific coast of Costa Rica.

2006). The two adjacent areas to the Gulf of Nicoya and to Golfo Dulce are, respectively, those off the Nicoya Peninsula and the bay of Coronado and both are coastal platforms open to the Pacific Ocean. The stations sampled in the Gulf of Nicoya (Vessels Skimmer and V. Hensen), Golfo Dulce and Coronado Bay (V. Hensen) are illustrated in Fig. 1. The area off the Nicoya Peninsula sampled by the Nishin Maru shrimp trawler is illustrated in Fig. 2.

In order to assemble a list of flatfish species collected by the research vessels Skimmer and $\mathrm{V}$. Hensen the publications by Bartels et al. (1983) and Bussing \& López (1996) were consulted. In addition, we also consulted the updated list by Vargas-Zamora, et al. (2019) of fish species from the Gulf of Nicoya collected by both vessels. Station data from both vessels were found in Price, Bussing, Bussing, Maurer, and Bartels (1980) for the Skimmer, and in Wolff \& Vargas (1994) for the V. Hensen survey.

Data on the species collected and depth distribution from the Nishin Maru survey off the Nicoya Peninsula were obtained from the Museum of Zoology, University of Costa Rica (MZUCR) catalogue cards. We also accessed the catalogue cards and flatfish specimens from the research vessels Skimmer and V. Hensen deposited in the collection of the Museum of Zoology. The names of several flatfish species were updated based on the web page World Register of Marine Species - WoRMS (http:// www.marinespecies.org/). Data on length and depth distribution of the species from the Gulf of Nicoya, Coronado Bay, and Golfo Dulce were obtained from the cruise reports by Price et al. (1980) and Wolff \& Vargas (1994). We also consulted information on depth available at the Shore Fishes of the Eastern Pacific: online Information System web page (Robertson \& Allen, 2015). Presence-absence data matrices of species per station were assembled for the Gulf of Nicoya and Golfo Dulce based on the report of the V. Hensen cruise (Wolff \& Vargas, 1994). Cluster analyses were performed to display the similary of stations based on the species composition. The Gulf of Nicoya matrix was made of 31 species x 12 stations, while the matrix for Golfo Dulce was based on 19 species x 13 stations. The matrices were analyzed with the program PAST (Hammer, Harper, \& Ryan, 2001) using the Sorensen similarity index.

Limited information was available from the National Institute of Fisheries and Aquaculture of Costa Rica (INCOPESCA) on landings of shrimp and by-catch (including flatfish) by the semi-industrial fleet operating on the Pacific coast of Costa Rica. The available data does not include species identifications. Total landings (kilograms of shrimp and bycatch including flatfish) from the semi-industrial fleet (vessels 17.3-27.6 m long) were available for the period 2000-2016. We visited (December 10, 2019) the fish counters at the Municipal Market of the port city of Puntarenas (Gulf of Nicoya) to verify if flatfish were offered there for sale.

\section{RESULTS}

The total number of species of flatfish found at the four sites on the Pacific coast of Costa Rica was 36 . There were 35 species collected by the Skimmer and V. Hensen (Table 1) while the $36^{\text {th }}$ species (Monolene danae) was collected by the Nishin Maru shrimp trawler off the Nicoya Peninsula at depths from 107 to $250 \mathrm{~m}$. The family Paralichthyidae 
TABLE 1

List of species of flatfish collected by the R.V. Skimmer (1979-1980, Gulf of Nicoya) and R.V. Victor Hensen (1993-1994, Gulf of Nicoya and Golfo Dulce). Pacific. Costa Rica

\begin{tabular}{|c|c|c|c|c|c|c|}
\hline No. & Species & A & B & $\mathrm{C}$ & $\mathrm{D}$ & $\mathrm{E}$ \\
\hline 01. & Achirus klunzingeri (Steindachner, 1880) & $*$ & & 19 & $15-64$ & 40 \\
\hline 02 & Achirus mazatlanus (Steindachner, 1869) & $*$ & $*$ & 30 & $8-64$ & 60 \\
\hline 03. & Achirus scutum (Günther, 1862) & $*$ & $*$ & 14 & $8-50$ & 46 \\
\hline 04. & Ancylopsetta dendritica Gilbert, $1890+$ & & $*$ & 35 & $22-60$ & 100 \\
\hline 05 & Citharichthys gilberti Jenkins \& Evermann, 1889 & $*$ & $*$ & 16 & $8-228$ & 48 \\
\hline 06. & Citharichthys platophrys Gilbert, $1891+$ & $*$ & $*$ & 12 & $8-228$ & 145 \\
\hline 07. & Cyclopsetta panamensis (Steindachner, 1876) + & * & $*$ & 37 & $15-235$ & 114 \\
\hline 08. & Cyclopsetta querna (Jordan \& Bollman, 1890) + & $*$ & & 43 & $8-65$ & 92 \\
\hline 09. & Engyophrys sanctilaurentii Jordan \& Bollman, 1890 & * & $*$ & 16 & $15-235$ & 235 \\
\hline 10. & Etropus crossotus Jordan \& Gilbert, $1882+$ & $*$ & & 17 & $8-45$ & 65 \\
\hline 11. & Etropus peruvianus Hildebrand, $1946+$ & $*$ & * & 13 & $15-65$ & 45 \\
\hline 12. & Hippoglossina bollmani Gilbert, $1890+$ & $*$ & & $\mathrm{~N}$ & $22-84$ & 191 \\
\hline 13. & Hippoglossina tetropthalma (Gilbert, 1890) + & $*$ & & 31 & $22-65$ & 233 \\
\hline 14. & Monolene asaedae Clark, 1936 & & $*$ & 11 & $187-200$ & 209 \\
\hline 15. & Monolene maculipinna Garman, 1899 & $*$ & * & 11 & $22-235$ & 385 \\
\hline 16. & Paralichthys woolmani Jordan \& Williams, $1897+$ & $*$ & & 25 & $22-84$ & 91 \\
\hline 17. & Perissias taeniopterus (Gilbert, 1890) & $*$ & & $\mathrm{~N}$ & 61 & 160 \\
\hline 18. & Syacium cf longidorsale Murakami \& Amaoka, 1992 & * & * & 8 & $22-200$ & 40 \\
\hline 19. & Syacium latifrons (Jordan \& Gilbert, 1882) + & $*$ & $*$ & 24 & $17-74$ & 95 \\
\hline 20. & Syacium ovale (Günter, 1864) + & $*$ & $*$ & 50 & $19-74$ & 90 \\
\hline 21. & Symphurus atramentatus Jordan \& Bollman, 1890 & * & * & 15 & $35-228$ & 120 \\
\hline 22. & Symphurus callopterus Munroe \& Mahadeva, 1989 & & * & 40 & $30-235$ & 320 \\
\hline 23. & Symphurus chabanaudi Mahadeva \& Munroe, 1990 & $*$ & & 20 & $8-45$ & 60 \\
\hline 24. & Symphurus elongatus (Günter, 1868) & $*$ & $*$ & 13 & $10-192$ & 100 \\
\hline 25. & Symphurus fasciolaris Gilbert, 1892 & $*$ & & $\mathrm{~N}$ & $35-65$ & 150 \\
\hline 26. & Symphurus gorgonae Chabanaud, 1948 & $*$ & $*$ & 10 & $19-228$ & 120 \\
\hline 27. & Symphurus leei Jordan \& Bollman, 1890 & $*$ & $*$ & 9 & $15-228$ & 115 \\
\hline 28. & Symphurus melanurus Clark, 1936 & $*$ & & 22 & $8-65$ & 35 \\
\hline 29. & Symphurus melasmatotheca Munroe \& Nizinski, 1890 & $*$ & * & 10 & $30-228$ & 110 \\
\hline 30. & Symphurus oligomerus Mahadeva \& Munroe, 1990 & $*$ & * & 12 & $32-200$ & 300 \\
\hline 31. & Symphurus undecimplerus Munroe \& Nizinski, 1990 & * & & $\mathrm{N}$ & 22 & 55 \\
\hline 32. & Symphurus williamsi Jordan \& Cuvier, 1895 & $*$ & & $\mathrm{~N}$ & $16-118$ & 55 \\
\hline 33. & Trinectes fimbriatus (Günter, 1862) & $*$ & & 9 & $8-50$ & 40 \\
\hline 34. & Trinectes fonsecensis (Günter, 1862) & $*$ & & 20 & $8-28$ & 107 \\
\hline 35. & Trinectes xanthurus Walker \& Bollinger, 2001 & $*$ & & 8 & $8-60$ & 25 \\
\hline 36. & Monolene danae Bruun, 1937 & \multicolumn{5}{|c|}{$\begin{array}{l}\text { It was found only by the research vessel Nishin } \\
\text { Maru at depths between } 107 \text { and } 250 \mathrm{~m}\end{array}$} \\
\hline
\end{tabular}

A. Gulf of Nicoya, B. Golfo Dulce. C. Maximum total lenght $(\mathrm{cm})$ of fish captured in both estuaries (N = no data). D. Depth (m) or depth range where captured. E. Maximum depth reported for the species by Robertson \& Allen (2015).

List of flatfish species based on data from Bartels et al. (1983), Bussing \& López (1996), Wolff (1996) and on specimens catalogued in the fish collection of the Museum of Zoology (MZUCR). Length data (C) from Price et al. (1980), and Wolff and Vargas (1994). + Species listed by Fischer et al. (1995) as commercially exploited in the Tropical Eastern Pacific. 
included 13 species of the genera Ancylopsetta (1), Citharichthys (2), Cyclopsetta (2), Etropus (2), Hippoglossina (2), Paralichthys (1) and Syacium (3). The Cynoglossidae was represented by 12 species of the genus Symphurus. The Achiridae had six species of the genera Achirus (3) and Trinectes (3). The Bothidae included five species of the genera Engyophrys (1), Monolene (3) and Perissias (1). Specimens of the family Pleuronectidae were not found in the four sites sampled. The most speciose genus was Symphurus with 12 species.

The Gulf of Nicoya estuary yielded 27 species during the Skimmer expedition over a depth range of 8 to $60 \mathrm{~m}$, while 31 species were found there during the V. Hensen survey at depths from 10 to $228 \mathrm{~m}$. In the Gulf of Nicoya, the richest locality was station 31 (45 m depth) with 16 species captured by the Skimmer and 13 by the V. Hensen ( $22 \mathrm{~m}$ ). The V. Hensen survey in Golfo Dulce yielded 19 species (Table 1) at depths from 23 to $235 \mathrm{~m}$. The most diverse stations there were $\mathrm{E}$ ( 7 species, $40 \mathrm{~m}$ depth) and $\mathrm{G}$ (7 species, $200 \mathrm{~m})$.

The maximum total lengths (TL) of the 30 species measured from both the Gulf of Nicoya and Golfo Dulce are included in Table 1 and ranged between $8 \mathrm{~cm}$ (Syacium cf longidorsale, Trinectes xanthurus) and $50 \mathrm{~cm}$ (S. ovale). Only 12 species were found with lengths over $20 \mathrm{~cm}$. The mean maximum total length of the 30 species was $20 \mathrm{~cm}$. Thirty-five species were collected over a depth range of 10 to $235 \mathrm{~m}$ in the Gulf of Nicoya and Golfo Dulce. Sixteen species were found there at greater depths than those reported in the Smithsonian Tropical Research Institute web page (Robertson \& Allen, 2015): Citharichthys gilberti, C. platophrys, Cyclopsetta panamensis, Etropus peruvianus, Paralichthys woolmani, Syacium cf longidorsale, Symphurus atramentatus, S. elongatus, S. gorgonae, S. leei, S. melasmatotheca, S. melanurus, S. undecimplerus, S. williamsi, Trinectes fimbriatus and T. xanthurus (Table 1).

The most frequently captured species in the Gulf of Nicoya, during the V. Hensen expedition, were Symphurus chabanaudi and
S. elongatus (6 stations each, Table 2) while eight species were found at one station each (Table 2). The most frequently captured species in Golfo Dulce was Symphurus leei (5 stations). Six species were found at one station each (Table 2).

The V. Hensen survey in Coronado Bay yielded 17 species in depths from 21 to $187 \mathrm{~m}$ (Table 3). Based on the collections deposited in the Museum of Zoology, a total of 13 species were collected off the Nicoya Peninsula by the Nishin Maru shrimp trawler over a depth range of 56 to $359 \mathrm{~m}$ (Table 4). When the four areas sampled are considered together, a total of 21 species $(58 \%)$ were found at depths greater than $100 \mathrm{~m}$. Monolene asaedae was collected at the deepest water range (254-359 m) off the Nicoya Peninsula (Table 4 and Table 5).

Cluster analysis from the V. Hensen data grouped the stations based on the similarity of the presence or absence of species at the stations (Fig. 3).The cluster for the Gulf of Nicoya may be interpreted as composed by three main groups (Fig. 3A). Group 1 has three subgroups of which the first includes stations 06 (6 spp 43 $\mathrm{m}$ deep) and 50 (2 spp, $32 \mathrm{~m}$ ). The two species present in station 50 (Symphurus oligomerus and Syacium ovale) were also present in station 06 . The second subgroup has two deep stations at the mouth of the estuary: station 52 (6 spp, $118 \mathrm{~m}$ ) and 53 (9 spp, $84 \mathrm{~m})$. The third subroup is composed by two distant stations 01 (7 spp, $35 \mathrm{~m}$ ) and 54 (6 spp, $228 \mathrm{~m}$ ), which have four species in common. Group 2 includes stations near Ballena Bay: station 31 (13 spp, $22 \mathrm{~m}$ ) and 51 (9 spp, $64 \mathrm{~m}$ ). Group 3 encloses two subgroups, the first is made by two distant stations: 30 (4 spp, $30 \mathrm{~m}$, ) and 43 (2 spp, $10 \mathrm{~m})$ which have two species in common (Symphurus chabanaudi and S. elongatus). The second subgroup comprises stations 35 (12 spp, $19 \mathrm{~m}$ ) and 45 (10 spp, $15 \mathrm{~m})$. Two pairs of stations $(52-53,31-51)$ that are closer geographically were grouped.

The cluster analysis for the V. Hensen Golfo Dulce data have no geographically closer stations grouped together and may comprise six main groups (Fig. 3B). Group 1 includes 
TABLE 2

R.V. Victor Hensen survey. Species present in four or more of the stations in the Gulf of Nicoya (12 stations) and Golfo Dulce (13 stations) and species found in one station only

\begin{tabular}{|c|c|c|}
\hline Species & Total & Station codes \\
\hline \multicolumn{3}{|l|}{ A. Gulf of Nicoya } \\
\hline Symphurus chabanaudi & 6 & 013031354345 \\
\hline Symphurus elongatus & 6 & 010630354353 \\
\hline Citharichthys platophrys & 5 & 0106525354 \\
\hline Achirus mazatlanus & 4 & 31353151 \\
\hline Cyclopsetta querna & 4 & 06303545 \\
\hline Syacium ovale & 4 & 06355051 \\
\hline Symphurus gorgonae & 4 & 01355354 \\
\hline Symphurus oligomerus & 4 & 06505253 \\
\hline Symphurus williamsi & 4 & 01313552 \\
\hline Achirus scutum & 1 & 45 \\
\hline Ancylopsetta dendritica & 1 & 31 \\
\hline Etropus crossotus & 1 & 35 \\
\hline Perissias taeniopterus & 1 & 51 \\
\hline Symphurus melasmatotheca & 1 & 54 \\
\hline Symphurus undecimplerus & 1 & 31 \\
\hline Trinectes fonsecensis & 1 & 45 \\
\hline Trinectes xanthurus & 1 & 45 \\
\hline \multicolumn{3}{|l|}{ B. Golfo Dulce } \\
\hline Symphurus leei & 5 & A B C E G \\
\hline Cyclopsetta panamensis & 4 & D E H I \\
\hline Syacium latifrons & 4 & C E F H \\
\hline Symphurus callopterus & 4 & D G I M \\
\hline Monolene maculipinna & 3 & G M I \\
\hline Achirus scutum & 1 & $\mathrm{H}$ \\
\hline Etropus peruvianus & 1 & $\mathrm{E}$ \\
\hline Monolene danae & 1 & G \\
\hline Syacium cf longidorsale & 1 & G \\
\hline Symphurus elongatus & 1 & B \\
\hline Symphurus oligomerus & 1 & G \\
\hline
\end{tabular}

\begin{tabular}{|c|c|c|}
\hline Location & Station & Number of species \\
\hline \multicolumn{3}{|c|}{$\begin{array}{l}\text { C. Total number of species found at each station. } \\
\text { Pacific coast, Costa Rica. }\end{array}$} \\
\hline \multirow[t]{12}{*}{ Gulf of Nicoya } & 01 & 7 \\
\hline & 06 & 6 \\
\hline & 30 & 4 \\
\hline & 31 & 13 \\
\hline & 35 & 12 \\
\hline & 43 & 2 \\
\hline & 45 & 10 \\
\hline & 50 & 2 \\
\hline & 51 & 9 \\
\hline & 52 & 6 \\
\hline & 53 & 9 \\
\hline & 54 & 6 \\
\hline \multirow[t]{13}{*}{ Golfo Dulce } & A & 1 \\
\hline & B & 3 \\
\hline & $\mathrm{C}$ & 3 \\
\hline & $\mathrm{D}$ & 6 \\
\hline & $\mathrm{E}$ & 7 \\
\hline & $\mathrm{F}$ & 5 \\
\hline & $\mathrm{G}$ & 7 \\
\hline & $\mathrm{H}$ & 3 \\
\hline & I & 4 \\
\hline & $\mathrm{J}$ & 0 \\
\hline & K & 0 \\
\hline & $\mathrm{L}$ & 0 \\
\hline & M & 3 \\
\hline
\end{tabular}

Data from Bussing \& López (1996), Wolff \& Vargas (1994), Wolff (1996) and specimens catalogued in the collection of Museum of Zoology (MZUCR).

station G (7 species, $200 \mathrm{~m}$ deep). Group 2 comprise station E (7 spp, $40 \mathrm{~m})$. Stations G and $\mathrm{E}$ have only two species in common: Symphurus leei and S. gorgonae. Group 3 is only composed by station D (6 spp, $30 \mathrm{~m})$. Group 4 comprise station F (5 spp, $74 \mathrm{~m}$ ). Group 5 is made of two stations: I (4 spp, $235 \mathrm{~m}$ ) and $\mathrm{M}$ (3 spp, $82 \mathrm{~m}$ ). Stations $\mathrm{M}$ and I have two species in common: $S$. callopterus and Monolene maculipinna. Group 6 includes seven stations in four subgroups: one made by station B (3 spp, $192 \mathrm{~m}$ ) and another by station H (3 species, $23 \mathrm{~m})$. A third subgroup is represented by station C (3 spp, $45 \mathrm{~m})$. Stations B and C have $S$. leei in common, while $\mathrm{C}$ and $\mathrm{H}$ have Syacium latifrons in common. The fourth subgroup is represented by station A (107 m) with only $S$. leei captured, and three stations (J, $52 \mathrm{~m}$; K, 54 m; L, 194 m) with no species found. No clear trends were found with depth. 
TABLE 3

List of species of flatfish from a transect (21 to $187 \mathrm{~m}$ deep) in front of the Térraba-Sierpe river mouth (Coronado Bay, Southeast Pacific coast of Costa Rica) collected by the R.V. Victor Hensen

\begin{tabular}{lccc}
\multicolumn{1}{c}{ Species } & Stations & Geographic Position & Depth (m) \\
Achirus mazatlanus & $\mathrm{Q}$ & $08^{\circ} 47^{\prime}-84^{\circ} 41^{\prime}$ & 21 \\
Ancylopsetta dendritica & $\mathrm{Q}$ & $08^{\circ} 47^{\prime}-84^{\circ} 41^{\prime}$, & 21 \\
Citharichthys gilberti & $\mathrm{Q}$ & $08^{\circ} 47^{\prime}-84^{\circ} 41^{\prime}$ & $103 \& 48$ \\
Citharichthys platophrys & $\mathrm{O}, \mathrm{P}$ & $08^{\circ} 47^{\prime}-84^{\circ} 00^{\prime} \& 08^{\circ} 46^{\prime}-83^{\circ} 46^{\prime}$ & $48 \& 21$ \\
Cyclopsetta panamensis & $\mathrm{P}, \mathrm{Q}$ & $08^{\circ} 46^{\prime}-83^{\circ} 46^{\prime} \& 08^{\circ} 47^{\prime}-84^{\circ} 41^{\prime}$ & 48 \\
Cyclopsetta querna & $\mathrm{P}$ & & $103 \& 48$ \\
Engyophrys sanctilaurentii & $\mathrm{O}, \mathrm{P}$ & $08^{\circ} 47^{\prime}-84^{\circ} 00^{\prime} \& 08^{\circ} 46^{\prime}-83^{\circ} 46^{\prime}$ & 187 \\
Hippoglossina bollmani & $\mathrm{N}$ & $08^{\circ} 47^{\prime}-84^{\circ} 03^{\prime}$ & 187 \\
Monolene asaedae & $\mathrm{N}$ & $08^{\circ} 47^{\prime}-84^{\circ} 03^{\prime}$ & $187 \& 103$ \\
Monolene maculipinna & $\mathrm{N}, \mathrm{O}$ & $08^{\circ} 47^{\prime}-84^{\circ} 03^{\prime} \& 08^{\circ} 47^{\prime}-84^{\circ} 00^{\prime}$, & $187 \& 103$ \\
Symphurus callopterus & $\mathrm{N}, \mathrm{O}$ & $08^{\circ} 47^{\prime}-84^{\circ} 03^{\prime} \& 08^{\circ} 47^{\prime}-84^{\circ} 00^{\prime}$ & 21 \\
Symphurus elongatus & $\mathrm{Q}$ & $08^{\circ} 47^{\prime}-84^{\circ} 41^{\prime}$ & $187 \& 103$ \\
Symphurus gorgonae & $\mathrm{N}, \mathrm{O}$ & $08^{\circ} 47^{\prime}-84^{\circ} 03^{\prime} \& 08^{\circ} 47^{\prime}-84^{\circ} 00^{\prime}$ & 48 \\
Symphurus leei & $\mathrm{P}$ & $08^{\circ} 46^{\prime}-83^{\circ} 46^{\prime}$ & 187 \\
Symphurus oligomerus & $\mathrm{N}$ & $08^{\circ} 47^{\prime}-84^{\circ} 03^{\prime}$ & 187 \\
Syacium latifrons & $\mathrm{N}$ & $08^{\circ} 47^{\prime}-84^{\circ} 03^{\prime}$ & 48 \\
Syacium ovale & $\mathrm{P}$ & &
\end{tabular}

Data from Bussing \& López (1996), Wolff \& Vargas (1994), Wolff (1996) and specimens catalogued in the collection of the Museum of Zoology (MZUCR)

TABLE 4

List of species of flatfish based on specimens collected by a shrimp trawler (Nishin Maru, 1987-1988) in coastal areas (56 to $350 \mathrm{~m}$ deep) on the Northwest Pacific (off Nicoya Peninsula) of Costa Rica and deposited in the collection of the Museum of Zoology (MZUCR)

\begin{tabular}{|c|c|c|}
\hline Species & Latitude N - Longitude W & Depth range, $m$ \\
\hline Engyophrys sanctilaurentii & $\begin{array}{l}09^{\circ} 37^{\prime}-85^{\circ} 30^{\prime} \\
10^{\circ} 19^{\prime}-85^{\circ} 52^{\prime}\end{array}$ & $\begin{array}{c}65-85 \\
111\end{array}$ \\
\hline Hippoglossina bollmani & $10^{\circ} 44^{\prime}-86^{\circ} 09^{\prime}$ & $189-193$ \\
\hline Hippoglossina tetropthalma & $\begin{array}{l}10^{\circ} 40^{\prime}-85^{\circ} 50^{\prime} \\
10^{\circ} 30^{\prime}-86^{\circ} 02^{\prime} \\
10^{\circ} 42^{\prime}-85^{\circ} 54^{\prime}\end{array}$ & $\begin{array}{c}165 \\
102 \\
56-72\end{array}$ \\
\hline Monolene asaedae & $\begin{array}{l}10^{\circ} 58^{\prime}-86^{\circ} 31^{\prime} \\
10^{\circ} 52^{\prime}-86^{\circ} 33^{\prime} \\
10^{\circ} 45^{\prime}-86^{\circ} 18^{\prime} \\
09^{\circ} 45^{\prime}-85^{\circ} 27^{\prime} \\
10^{\circ} 34^{\prime}-86^{\circ} 16^{\prime} \\
11^{\circ} 00^{\prime}-86^{\circ} 32^{\prime} \\
10^{\circ} 25^{\prime}-85^{\circ} 55^{\prime} \\
10^{\circ} 06^{\prime}-85^{\circ} 58^{\prime} \\
10^{\circ} 47^{\prime}-86^{\circ} 14^{\prime} \\
10^{\circ} 45^{\prime}-86^{\circ} 15^{\prime} \\
10^{\circ} 47^{\prime}-86^{\circ} 18^{\prime} \\
11^{\circ} 00^{\prime}-86^{\circ} 17^{\prime}\end{array}$ & $\begin{array}{c}168-179 \\
188-205 \\
207 \\
85 \\
255-258 \\
159-180 \\
68-72 \\
107-250 \\
203-206 \\
206-215 \\
245-359 \\
159-164\end{array}$ \\
\hline Monolene danae & $10^{\circ} 06^{\prime}-85^{\circ} 58^{\prime}$ & $107-250$ \\
\hline
\end{tabular}


TABLE 4 (Continued)

$\begin{array}{lcc}\text { Species } & \text { Latitude N - Longitude W } & \text { Depth range, m } \\ \text { Monolene maculipinna } & 10^{\circ} 52^{\prime}-86^{\circ} 33^{\prime} & 188-205 \\ & 10^{\circ} 07^{\prime}-85^{\circ} 51^{\prime} & 71-82 \\ & 10^{\circ} 04^{\prime}-85^{\circ} 52^{\prime} & 65-170 \\ & 10^{\circ} 33^{\prime}-86^{\circ} 02^{\prime} & 102-178 \\ \text { Syacium ovale } & 10^{\circ} 23^{\prime}-85^{\circ} 55^{\prime} & 67-70 \\ \text { Symphurus atramentatus } & 10^{\circ} 34^{\prime}-86^{\circ} 10^{\prime} & 156-182 \\ \text { Symphurus callopterus } & 10^{\circ} 34^{\prime}-86^{\circ} 14^{\prime} & 215-225 \\ & 09^{\circ} 41^{\prime}-85^{\circ} 21^{\prime} & 220 \\ & 10^{\circ} 44^{\prime}-85^{\circ} 49^{\prime} & 61-82 \\ \text { Symphurus chabanaudi } & 10^{\circ} 04^{\prime}-85^{\circ} 52^{\prime}, & 65-170 \\ \text { Symphurus gorgonae } & 10^{\circ} 54^{\prime}-86^{\circ} 22^{\prime}, & 191-192 \\ \text { Symphurus leei } & 10^{\circ} 08^{\prime}-85^{\circ} 52^{\prime} & 67-106 \\ & 10^{\circ} 32^{\prime}-85^{\circ} 53^{\prime} & 80-85 \\ & 11^{\circ} 00^{\prime}-86^{\circ} 32^{\prime} & 159-180 \\ & 10^{\circ} 42^{\prime}-85^{\circ} 54^{\prime} & 56-72 \\ & 10^{\circ} 37^{\prime}-85^{\circ} 55^{\prime} & 91-93 \\ & 10^{\circ} 07^{\prime}-85^{\circ} 50^{\prime} & 72-89 \\ & 10^{\circ} 55^{\prime}-86^{\circ} 03^{\prime} & 116-144\end{array}$

Data obtained directly from INCOPESCA for the period 2000-2016 is included in Fig. 4. A minimum of $365.5 \mathrm{~kg}$ of flatfish was discharged in 2001 representing $0.03 \%$ of the total $1289951.5 \mathrm{~kg}$ of shrimp and bycatch landed. A peak of $2825707 \mathrm{~kg}$ of shrimp and bycatch, of which $13414 \mathrm{~kg}(0.47 \%)$ were flatfish was reported for the year 2013 followed by a decline. A total of $694287 \mathrm{~kg}$ of shrimp and bycatch was discharged in 2016 of which flatfish were represented by $1126 \mathrm{~kg}(0.16 \%)$. The relative percentage of flatfish in the total captures over the period 2000-2016 was small (mean $0.19 \%$ ) with a maximum of $0.57 \%$ (8113 kg) for the year 2004 (Fig. 4).

During our visit to the Municipal Market we found only one store selling a few flatfish (Possibly Etropus crossotus). The longest (estimated at $40 \mathrm{~cm}$ ) headless and eviscerated specimen had a weight of $950 \mathrm{gr}$.

\section{DISCUSSION}

Data on the species richness and depth distribution of flatfishes from the Eastern Tropical Pacific are scarce. However, the number of flatfish species of the Pacific coast of Costa Rica appears comparable to that found in other tropical regions such as that reported for the Kerala coast $\left(8^{\circ} \mathrm{N}\right)$ of India where 34 species and 17 genera were present in bycatch collections (Bijukumar \& Deepthi, 2009). In contrast, a study in a Guinea-Bissau estuary $\left(11^{\circ} \mathrm{N}\right.$, Africa) collected eight flatfish species using a beam trawl net (Van der Veer et al., 1995). Other factors such as depth, environmental parameters, sampling effort and gear type may influence the local number of species of this group of fishes as discussed by Gibson (1994). A relatively high number of species of flatfish was also found in a temperate embayment 

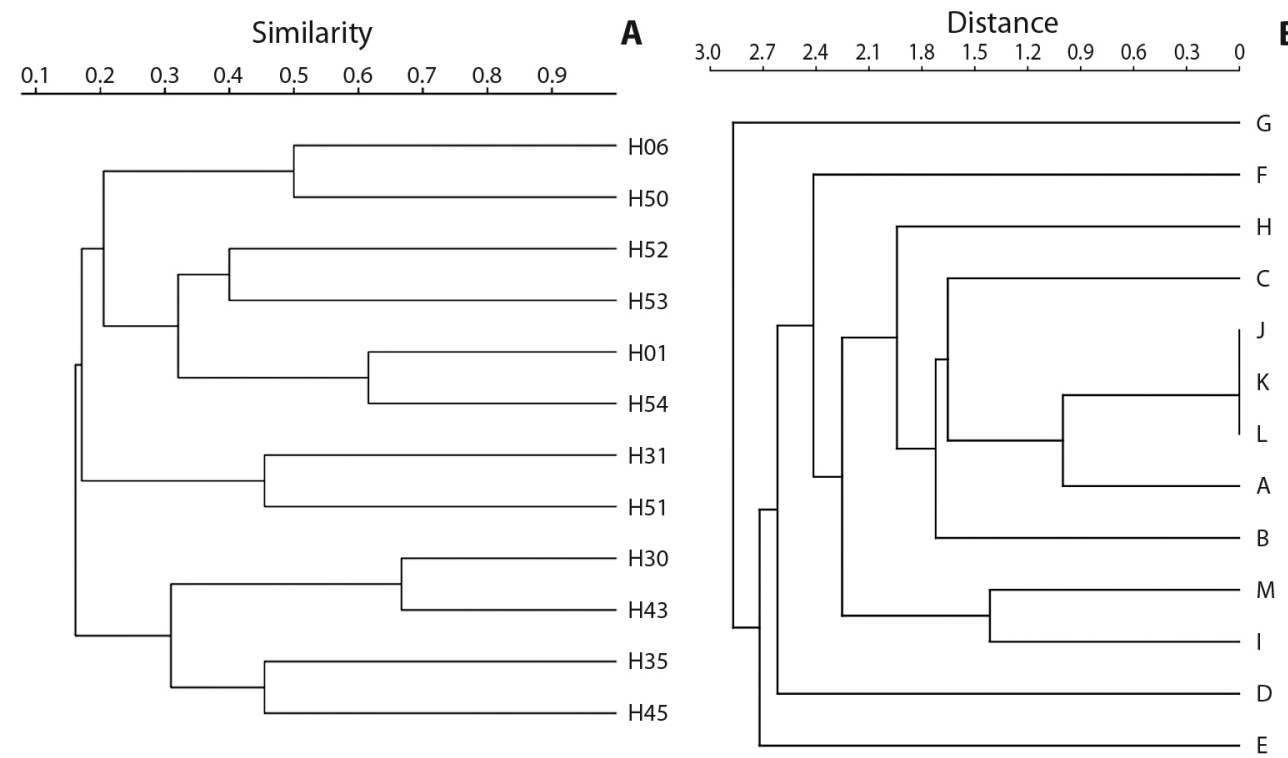

Fig. 3. R.V. Victor Hensen (1993-1994). Dendogram resulting from cluster analysis (Sorensen index). A. Gulf of Nicoya (31 species x 12 stations). B. Golfo Dulce (19 species x 13 stations). No species were found at stations J, K \& L. Pacific coast of Costa Rica.

\section{TABLE 5}

List of 21 species of flatfish found at depths deeper than $100 \mathrm{~m}$ in the four areas sampled on the Pacific coast of Costa Rica

\begin{tabular}{lc}
\multicolumn{1}{c}{ Species } & Maximum depth (m) \\
\hline Citharichthys gilberti & 228 \\
Citharichthys platophrys & 228 \\
Cyclopsetta panamensis & 235 \\
Engyophrys sanctilaurentii & 235 \\
Hippoglossina bollmani & 193 \\
Hippoglossina tetropthalma & 165 \\
Monolene asaedae & 359 \\
Monolene danae & 250 \\
Monolene maculipinna & 235 \\
Syacium ovale & 220 \\
Syacium latifrons & 187 \\
Syacium cf longidorsale & 200 \\
Symphurus atramentatus & 228 \\
Symphurus callopterus & 235 \\
Symphurus chabanaudi & 182 \\
Symphurus elongatus & 192 \\
Symphurus gorgonae & 228 \\
Symphurus leei & 228 \\
Symphurus melasmatotheca & 228 \\
Symphurus oligomerus & 207 \\
Symphurus williamsi & 118 \\
\hline
\end{tabular}

$\left(35^{\circ} \mathrm{N}\right.$, Wakasa Bay, Japan) where 41 species were captured between 60 to $260 \mathrm{~m}$ (Minami \& Tanaka,1992). In contrast, studies in other temperate regions indicate lower numbers particularly in shallow embayments: A beam trawl study of the Sado estuary $\left(38^{\circ} \mathrm{N}, 10 \mathrm{~m}\right.$ deep, Portugal) yielded 12 species and seven genera (Nogueira-Cabral, 2000). A beam trawl survey of the shallow Barataria Bay estuary $\left(29^{\circ} \mathrm{N}\right.$, $2 \mathrm{~m}$ deep, U.S.A,) captured only seven species (Allen \& Baltz, 1997). Moreover, the Guanabara Bay estuary in Brazil $\left(22.5^{\circ} \mathrm{S}, 1\right.$ to $30 \mathrm{~m}$ deep) yielded 16 species (Silva-Junior, Santos, Chagas-Macedo, Numan, \& Vianna, 2019), while the nearby Sepetiba Bay $\left(23^{\circ}\right.$ $\mathrm{S}$, less than $5 \mathrm{~m}$ deep) was characterized by five species (Guedes \& Araujo, 2008). For the Eastern Tropical Pacific region Minami \&Tanaka (1992) reported 92 species of flatfish. On this region a study on the Gulf of California $\left(25^{\circ} \mathrm{N}\right.$, Mexico) 15 species of five families were reported there at depths from 10 to 64 m by Rábago-Quiróz, López-Martínez, Herrera-Valdivia. Nevárez-Martínez, \& RodríguezRomero (2008). Most of the above-mentioned studies were conducted in shallow waters. 

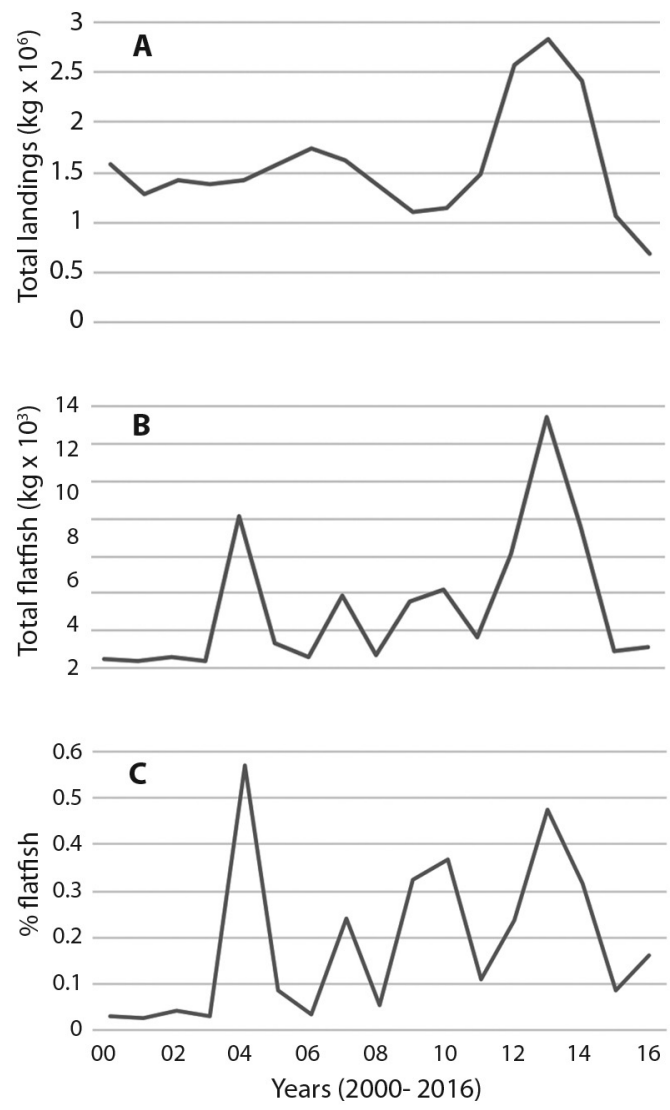

Fig. 4. Total landings $(\mathrm{kg})$ by the semi-industrial fishing fleet (vessels of 17.3 to $27.6 \mathrm{~m}$ long) for the period 20002016. A. Total landings (shrimp and bycatch including fish, $\mathrm{kg} \times 10^{6}$ ). B. Total landings of flatfish, $\mathrm{kg} \times 10^{3}$. C. Percentage (\%) of the total landings represented by flatfish. Pacific coast of Costa Rica.

The relatively high number of species found by trawling in Costa Rica was probably related to the wide water depth range ( 8 to $359 \mathrm{~m}$ ) covered by the three survey vessels, the numerous stations, and the use of otter and beam trawl nets during de V. Hensen survey.

This greater range also allowed sampling over a variety of sediment types ranging from sand to mud and mixtures of both. Flatfish live on bottom sediments whose composition may influence fish habitat preferences, as the study by Stoner and Abookire (2002) indicates for the Alaskan Hippoglossus stenolepis. There are some data on the sediment composition found in the Gulf of Nicoya by the Skimmer expedition (Vargas, Dean, Maurer, \& Orellana, 1985) and in Golfo Dulce by the V. Hensen survey (León-Morales \& Vargas, 1998) indicating a wide range of patchy sediment types, from very soft muds to compact mixtures. However, sedimentary sampling stations differ from those of the fish surveys and a clear association of fish distribution with sediment types based on those reports is difficult to assess.

The results of the cluster analyses probably reflect habitat preferences among the flatfish species inhabiting the Gulf of Nicoya and Golfo Dulce. The fact that over 30 species can coexist is important in the particular context of the various species of Symphurus found in both embayments. The benthic invertebrate fauna of both ecosystems includes a variety of possible food items with a patchy distribution over different mixtures of sediments (Maurer \& Vargas, 1984; Vargas et al, 1985; León-Morales \& Vargas, 1998) that may influence habitat partitioning by flatfish. In addition, both systems include many other species of fish (VargasZamora et al 2019) as potential prey items. Habitat partitioning by five species of flatfish based on different prey items has been reported by Guedes and Araujo (2008) for a tropical bay in Brazil. Accoring to Cabral, Lopes and Loeper (2002) members of the family Bothidae are day active predators while those of the familiy Soleidae are mostly night feeders. This different behaviours may serve to facilitate coexistence of the assemblages of flatfish species in the four areas sampled on the Pacific coast of Costa Rica.

The size range of flatfish reported by Rábago-Quiróz et al. (2008) for the Gulf of California was from 2 to $38 \mathrm{~cm}$, with only a few individuals of the genera Paralichthys longer than $25 \mathrm{~cm}$. They also reported maximum size ranges found in the literature for several species which are also found in the Pacific coast of Costa Rica, like: Achirus mazatlanus $(21 \mathrm{~cm})$, Citharichthys gilberti $(27 \mathrm{~cm})$, Etropus crossotus (20), Paralichthys woolmani (80 $\mathrm{cm})$, Symphurus chabanaudi $(25 \mathrm{~cm})$ and Syacium ovale $(23 \mathrm{~cm})$. Of the species collected 
in Costa Rica, A. mazatlanus $(30 \mathrm{~cm})$ and $S$. ovale $(50 \mathrm{~cm})$ appear to be length records for the region. Thus, the range of maximum total lengths for the 36 species found in this study $(8-50 \mathrm{~cm})$ appears as expected for the region, with several exceptions.

Rábago-Quiróz, López-Martínez, NevárezMartínez, \& Morales-Bojorquez (2015) also suggested that flatfishes of less than $13.7 \mathrm{~cm}$ were recruits. If we accept this length, a total of 14 species found in this study were problably recruits. This fact emphasizes the negative impact of benthic trawling gear on the marine benthos (Campos, Burgos \& Gamboa, 1984; Jones, 1992).

On the Pacific coast of Costa Rica at least 21 species $(58 \%$ of total) were found in waters deeper than $100 \mathrm{~m}$ and thus probably exposed to low oxygen concentrations characteristic of hypoxia. The results of the V. Hensen expedition indicate that low oxygen concentrations were found in waters deeper than $100 \mathrm{~m}$ at the mouths of both the Gulf of Nicoya and Golfo Dulce (Wolff \& Vargas, 1994; Vargas-Zamora et al 2019). These low oxygen concentrations were close or below $2 \mathrm{mg} \mathrm{O}_{2} / \mathrm{L}$, an accepted indicator of hypoxia (Hofmann, Peltzer, Waltz, \& Brewer, 2011). Oxygen concentrations as low as $0.2 \mathrm{mg} / \mathrm{L}$ were found at a $200 \mathrm{~m}$ deep station in the inner portion of Golfo Dulce (Acuña-González, Vargas-Zamora, \& CórdobaMuñoz 2006). However, information on the tolerance of tropical flatfish to low oxygen concentrations is scarce. The report by Switzer, Chesney, and Baltz (2009) who studied the distribution of seven species from the Northern Gulf of Mexico found that hypoxic environments were generally avoided by flatfishes leading to large areas unsuitable for many species.

The expeditions of the research vessels Skimmer, V. Hensen and Nishin Maru took place in 1979-1980, 1987-1988 and 1993-1994, respectively. During those years a relatively large fleet of shrimp trawlers was operating on the Pacific coast of Costa Rica. Fisheries statistical data for the period 1987-2005 are available in Araya, Vásquez, Marín, Palacios, Soto,
Mejía, Shimazu, and Hiramatsu (2007) but their study focused on other commercially important fish species and shrimp rather than on flatfish. However, they included photographs of 12 local species of flatfish. The number of trawlers has been drastically reduced recently and the remaining trawl fishing licences expired in 2018. A few flatfish are presently captured by other types of gear and are occasionally offered for sale at local markets.

The data gathered by the National Fisheries Institute (INCOPESCA) from 2000-2016 includes the total captures of flatfish (not identified to species level) by the semi-industrial fleet. The relative importance of these captures is below $1 \%$. This percentage is lower than that reported by Rábago-Quiróz et al. (2015) for the Gulf of California where flatfishes represented between 5 to $10 \%$ of the total by-catch. According to Nair and Gopalakrishnan (2014) flatfish landing data around the world generally do not include species identifications and 54-80 $\%$ of landings of tropical flatfish are of unidentified species. Thus, scientific survey data like the presented in this study are a key to address biodiversity and management issues.

Despite the relatively low percentage of flatfish in commercial landings, their importance on the functioning of the benthic-pelagic ecosystems is crucial. This role has been evaluated for both the Gulf of Nicoya and Golfo Dulce by means of trophic models that estimated the impact on the system of the removal or addition of the biomass of groups or organisms or of detritus (Wolff, Hartmann, \& Koch. 1996; Wolff, Chavarría, Koch, \& Vargas, 1998; Alms \& Wolff, 2019; Sánchez-Jiménez, Fujitani, MacMillan, Schluter, \& Wolff, 2019). The historical data presented in this study, together with the recent reduction in fishing pressure and bottom damage, provide a unique framework for a future evaluation of the status of flatfish populations on the Pacific coast of Costa Rica. Of relevance is the updating of the trophic models in view of the increasing impact of both coastal development and other environmental tensors. 
Ethical statement: authors declare that they all agree with this publication and made significant contributions; that there is no conflict of interest of any kind; and that we followed all pertinent ethical and legal procedures and requirements. All financial sources are fully and clearly stated in the acknowledgements section. A signed document has been filed in the journal archives.

\section{ACKNOWLEGMENTS}

We thank Jeffrey Sibaja for performing the cluster analysis and Sergio Aguilar for preparing the figures. The cruises aboard the R.V. Skimmer were part of the Agreement of Cooperation between UCR-CIMAR and the University of Delaware, Lewes, Delaware (U.S.A.). The cruises aboard the R.V. Victor Hensen were part of the Agreement of Cooperation between UCR-CIMAR and the Centre for Marine Tropical Ecology (ZMT, Bremen (Germany). Surveys by the Nishin Maru trawler were possible thanks to the support of the Japanese International Cooperation Agency (JICA), Japan.

\section{RESUMEN}

Riqueza de especies de lenguados (Pleuronectiformes) y distribución por profundidad en el Golfo de Nicoya, Golfo Dulce y dos áreas adyacentes en la costa del Pacifico de Costa Rica. Introducción: Es escasa la información sobre el número de especies y la distribución batimétrica de los lenguados del Pacífico Este Tropical. Esos datos son importantes para evaluar cambios en los ecosistemas debidos a tensores locales, regionales y globales. Objetivo: Proveer información de la presencia, distribución batimétrica y longitudes de especies de lenguados recolectados por red de arrastre. Métodos: Evaluaciones de los peces mediante redes de arrastre fueron conducidas en cuatro sitios a lo largo de la costa del Pacífico de Costa Rica por los buques de investigación Skimmer (1979-1980), Nishin Maru (1987-1988) y Victor Hensen (1993-1994). Se consultó las listas publicadas de especies, se revisó ejemplares depositados en el museo y se integró una lista actualizada de especies de lenguados. Resultados: Un total de 36 especies de lenguados fueron encontrados en un ámbito de profundidad de 8 a $359 \mathrm{~m}$. La familia Paralichthyidae incluyó 13 especies seguida por los Cynoglossidae con 12 especies, Achiridae tuvo seis y
Bothidae cinco especies. Treinta y cinco especies fueron recolectadas entre 10 y $235 \mathrm{~m}$ en el Golfo de Nicoya y Golfo Dulce. Monolene asadeae fue recolectada aguas afuera en un ámbito de profundidad de 254-359 m. El Golfo de Nicoya produjo 27 especies durante la expedición del Skimmer y en un ámbito de profundidad de 8 a $60 \mathrm{~m}$, mientras que 31 especies fueron encontradas durante el muestreo del V. Hensen en profundidades entre los $10 \mathrm{y}$ $228 \mathrm{~m}$. El muestreo del V. Hensen en el Golfo Dulce (20 a $235 \mathrm{~m}$ ) produjo 19 especies y 17 en Bahía de Coronado (21-187 m). Afuera de la península de Nicoya (56-359 m) 13 especies fueron recolectadas por el camaronero Nishin Maru. Un total de 21 especies (58 \%) fueron encontradas a profundidades mayores de $100 \mathrm{~m}$ y posiblemente expuestas a las bajas concentraciones de oxígeno. Durante el muestreo del V. Hensen, Symphurus chabanaudi y S. elongatus fueron capturados más frecuentemente en el Golfo de Nicoya, mientras $S$. leei lo fue en Golfo Dulce. El tamaño (Longitud Total) de 33 especies medidas en ambos Golfo de Nicoya y Golfo Dulce oscilaron entre $8 \mathrm{~cm}$ (Syacium $\mathrm{cf}$ longidorsale, Trinectes xanthurus) y $50 \mathrm{~cm}$ (S. ovale). Solo 12 especies fueron encontradas con longitudes mayores de $20 \mathrm{~cm}$. Datos de desembarcos de lenguados por la flota semi-industrial para el periodo 2000-2016 indican que este grupo representa menos del $1 \%$ de los desembarcos totales (camarones y fauna acompañante), con un mínimo de 365 $\mathrm{kg}$ en 2001 y un máximo de $13414 \mathrm{~kg}$ en 2013. Conclusiones: Los análisis de conglomerados basados en datos de presencia-ausencia para el Golfo de Nicoya y Golfo Dulce revelaron baja similitud de estaciones indicando partición del hábitat entre las especies. La diversidad de la fauna de lenguados de la costa del Pacífico de Costa Rica aparece relativamente alta pero comparable con la encontrada en otras regiones tropicales. El número de buques arrastreros ha disminuido significativamente en el Pacífico de Costa Rica después del 2014. Esta reducción del impacto en las poblaciones y la lista actualizada de lenguados proveen una buena base para un nuevo estudio de las poblaciones de peces. Ambas son importantes para una futura actualización de los modelos tróficos disponibles para el Golfo de Nicoya y Golfo Dulce y su utilidad como herramientas para un mejor manejo de los ecosistemas.

Palabras clave: Peces planos; lenguados; estuario; bentos; redes de arrastre; Symphurus.

\section{REFERENCES}

Acuña-González, J.A., Vargas-Zamora, J.A., \& CórdobaMuñoz, R. (2006). A snapshot view of some vertical distributions of water parameters at a deep (200 m) station in the fjord-like Golfo Dulce embayment, Costa Rica. Revista de Biología Tropical, 54(Suppl. 1), S193-S200.

Alms, V., \& Wolff, M. (2019). The Gulf of Nicoya (Costa Rica) fisheries system: Two decades of change. 
Marine and Coastal Fisheries: Dynamics, Management and Ecosystem Science, 11, 139-161.

Allen, R.L., \& Baltz, D.M. (1997). Distribution and microhabitat use by flatfishes in a Lousiana estuary. Envrionmental Biology of Fishes, 50, 85-103.

Araya, H., Vásquez, A.R., Marín, B., Palacios, J.A., Soto, R.L., Mejía, F., Shimazu, Y., \& Hiramatsu, K. (2007). Reporte del Comité de Evaluación de Recursos Pesqueros. No 1 y No 2. Proyecto manejo sostenible de las pesquerías para el Golfo de Nicoya. San José: INCOPESCA-UNA-JICA.

Bartels, C., Price, K.S., López, M., \& Bussing, W.A. (1983). Occurrence, distribution, abundance and diversity of fishes in the Gulf of Nicoya, Costa Rica. Revista de Biología Tropical, 31, 75-101.

Bartels, C., Price, K.S., López-Bussing, M., \& Bussing. W.A. (1984). Ecological assessment of finfish as indicators of habitats in the Gulf of Nicoya, Costa Rica. Hydrobiologia, 112, 197-207.

Bijukumar, A., \& Deepthi, G.R. (2009). Diversity of flatfishes (Order Pleuronectiformes) along the Kerala coast of India, with notes on two rare species. Indian Journal of Fisheries, 56, 211-214.

Bussing, W.A., \& López, M.I. (1996). Fishes collected during the R.V. Victor Hensen Expedition (1993/ 1994). Revista de Biología Tropical, 44(Suppl. 3), S183-S186.

Bussing, W.A., \& López, M.I. (2015). Peces demersales $y$ pelágicos costeros del Pacifico de Centroamérica Meridional. / Demersal and pelagic fishes of the Pacific coast of lower Central America. San José: Editorial de la Universidad de Costa Rica.

Cabral, H.N., Lopes, M., \& Loeper, R. (2002). Trophic niche overlap between flafishes in a nursey area on the Portuguese coast. Scientia Marina, 66, 293-300.

Campos, J., Burgos, B., \& Gamboa, C. (1984). Effect of shrimp trawling on the commercial ichthyofauna of the Gulf of Nicoya, Costa Rica. Revista de Biología Tropical, 32, 203-207.

Fischer, W., Krupp, F., Schneider, W., Sommer, G., Carpenter, K.E., \& Niem, V.H. (1995). Guía FAO para la identificación de especies para los fines de la pesca Vol. II Vertebrados (Parte 1). Roma, Italia: Food and Agriculture Organization of the United Nations-FAO.

Gibson, R.N. (1994). Impact of habitat quality and quantity on the recruitment of juvenile flatfishes. Netherlands Journal of Sea Research, 32, 191-208.

Guedes, A.P.P., \& Araujo, F.G. (2008). Trophic resource partitioning among five flatfish species (Actinopterygii, Pleuronectiformes) in a tropical bay in south-eastern Brazil. Journal of Fish Biology, 72, 1035-1054.
Hammer, O.D., Harper, A.T., \& Ryan, P.D. (2001) PAST, Paleontological Statistics Software Package for Education and Data Analysis. Paleontologia Electronica, 4, 1-9.

Hofmann, A.F., Peltzer, E.T., Walz, P.M., \& Brewer, P.G. (2011). Hypoxia by degrees: Establishing definitions for a changing ocean. Deep Sea Research Part I: Oceanographic Research Papers, 58, 1212-1226.

Jones, J.B. (1992). Environmental impact of trawling on the seabed: A review. New Zealand Journal of Marine and Freshwater Research, 26, 59-67

León-Morales, R., \& Vargas, J.A. (1998). Macroinfauna of a tropical fjord-like embayment, Golfo Dulce, Costa Rica. Revista de Biología Tropical, 46(Suppl. 6), S81-S90.

Maurer, D.M., \& Vargas, J.A. (1984). Diversity of softbottom benthos in a tropical estuary: Gulf of Nicoya, Costa Rica. Marine Biology, 81, 97-106.

Minami, T., \& Tanaka, M. (1992). Life history cycles in flatfish from the Northwestern Pacific with particular reference to their early life histories. Netherlands Journal of Sea Research, 29, 35-48.

Nair, R.J., \& Gopalakrishnan, A. (2014). A review on the fisheries, taxonomy and status of the flatfishes in tropical waters. Reviews in Fishery Science \& Aquaculture, 22, 175-183.

Nogueira-Cabral, H. (2000). Distribution and abundance patterns of flatfishes on the Sado estuary, Portugal. Estuaries, 23, 351-368.

Pauly, D. (1994). A framework for latitudinal comparisons of flatfish recruitment. Netherlands Journal of Sea Research, 32, 107-118.

Price, K., Bussing, M., Bussing, W.A., Maurer, D., \& Bartels, C. (1980). Finfish survey. In D. Maurer, C. Epifanio, \& K. Price (Eds.), Ecological assessment of finfish and megabenthic invertebrates as indicators of natural and impacted habitats in the Gulf of Nicoya, Costa Rica. (pp. 83-144). Progress report of the International Sea Grant Program. Delaware, U.S.A: University of Delaware.

Rábago-Quiróz, C.H., López-Martínez, J., Herrera-Valdivia, E., Nevárez-Martínez, M.O., \& RodríguezRomero, J. (2008). Population dynamics and spatial distribution of flatfish species in shrimp trawl bycatch in the Gulf of California. Hidrobiologica, 18, 177-188.

Rábago-Quiróz, C.H., López-Martínez, J., Nevárez-Martínez, M.O., \& Morales-Bojorquez, E. (2015). Abundance and size structure of flatfish species on the West side of the Gulf of California, Mexico. Revista de Biología Marina y Oceanografia, 50, 235-247.

Robertson, D.R., \& Allen, G.R. (2015). Shore fishes of the Tropical Eastern Pacific: online information system 
(Version 2.0, Data base). Balboa, Panamá: Smithsonian Tropical Research Institute. Retrieved from https://biogeodb.stri.si.edu/sftep/es/pages

Sánchez-Jiménez, A., Fujitani, M., MacMillan, D., Schluter, A., \& Wolff, M. (2019). Connecting a Trophic Model and local knowledge to improve fisheries management: The case of the Gulf of Nicoya, Costa Rica. Frontiers in Marine Science, 6, 1-17.

Silva-Junior, L.C., Santos, S.R., Chagas-Macedo, M., Numan, G.W., \& Vianna, M. (2019). Use of a species rich and highly eutrophic tropical estuary in the South Atlantic by Pleuronectiformes (Telostei: Acanthopterygii). Biota Neotropica, 19, 1-12.

Stoner, A.W., \& Abookire, A.A. (2002). Sediment preferences and size-specific distribution of youg-of-the-year Pacific halibut in an Alaska nursery. Journal of Fish Biology, 61, 540-559.

Svendsen, H., Rosland, R., Myking, S., Vargas, J.A., Lizano, O.G., \& Alfaro, E.J. (2006). A physical-oceanographic study of Golfo Dulce, Costa Rica. Revista de Biología Tropical, 54(Suppl. 1), S147-S170.

Switzer, T.S., Chesney, E.J., \& Baltz, D.M. (2009). Habitat selection by flatfishes in the northern Gulf of Mexico: implications for susceptibility to hypoxia. Journal of Experimental Marine Biology and Ecology, 381, 551-564.

Van der Veer, H.W., Adriaans, E.J., Bolle, L.J., Dankers, N., Da Fonseca, L.M., Walter, P.A., \& Witte, J. (1995). Ecological observations of juvenile flatfish in a tropical estuary: Arquipelago Dos Bigajos, Guinea-Bissau. Netherlands Journal of Sea Research, 34, 221-228.
Vargas, J.A., Dean, H.K., Maurer, D., \& Orellana, P. (1985) Lista preliminar de invertebrados asociados a los sedimentos del Golfo de Nicoya, Costa Rica. Brenesia, 24, 327-342.

Vargas-Zamora, J.A., López-Sánchez, M.I., \& RamírezCoghi, A.R. (2019). Peces del Golfo de Nicoya, Pacífico, Costa Rica: Actualización de las listas de los buques científicos Skimmer y Victor Hensen. Revista de Biología Tropical, 67(4), 913-934.

Voorhis, A., Epifanio, C.E., Maurer, D., Dittel, A.I., \& Vargas, J.A. 1983. The estuarine character of the Gulf of Nicoya, an embayment on the Pacific coast of Central America. Hydrobiologia, 99, 225-237.

Wolff, M., \& Vargas, J.A. (1994). R.V. Victor Hensen Costa Rica Expedition 1993/1994 Cruise Report. Bremen, Germany: Centre for Tropical Marine Ecology.

Wolff, M. (1996). Demersal fish assemblages along the Pacific coast of Costa Rica: a quantitative and multivariate assessment based on the Victor Hensen Costa Rica Expediton 1993 / 1994. Revista de Biología Tropical, 44(Suppl. 3), S187-S214.

Wolff, M., Hartmann, H.J., \& Koch, V. (1996). A pilot trophic model for Golfo Dulce, a fjord-like tropical embayment, Costa Rica. Revista de Biología Tropical, 44(Suppl. 3), S215-S231.

Wolff, M., Chavarría, J., Koch, V., \& Vargas, J.A. (1998). A trophic flow model of the Golfo de Nicoya, Costa Rica. Revista de Biología Tropical, 46(Suppl. 6), S63-S79. 